Chapter 2

\title{
Application of System Analysis for Thermal Power Plant Heat Rate Improvement
}

\author{
M.N. Lakhoua, M. Harrabi and M. Lakhoua \\ Additional information is available at the end of the chapter \\ http://dx.doi.org/10.5772/55498
}

\section{Introduction}

In order to improve the performance of a thermal power plant (TPP), it is necessarily to adopt performance monitoring and heat rate improvement. To improve efficiency, the engineer must knew the heat input, the mass of fuel, the fuel analysis and the $\mathrm{kW}$ rating generation in order to determine the actual heat rate. After the actual heat rate calculated and understood, losses must be identified and understood. Good communication and teamwork between the engineer and staff within the TPP is essential to success [1-2].

In fact, the heat rate is defined in units of Btu $/ \mathrm{kWh}(\mathrm{KJ} / \mathrm{kWh})$ and is simply the amount of heat input into a system divided by the amount of power generated by of a system [1].

The calculation of the heat rate enable to inform us on the state of the TPP and help the engineer to take out the reasons of the degradation of the TPP heat rate in order to reach the better one recorded at the time of acceptance test when the equipment was new and the TPP was operated at optimum. Therefore, this TPP heat rate value is realistic and attainable for it has been achieved before [1-2].

The global efficiency of a TPP is tributary of a certain number of factors and mainly of the furnace efficiency. Otherwise, there is place to also notice that with regards to the turbine and the alternator that are facilities of big importance in the constitution of a TPP, the degradation of their respective efficiencies hardly takes place long-term of a manner appreciable and this by reason of the ageing of some of their organs as: stationary and mobile aubages usury; increase of the internal flights; usury of alternator insulations, etc.

The objective of this paper is to analyze the different losses of a TPP therefore to implant solutions in order to act in time and to improve its efficiency. Appropriate performance parameters can enable the performance engineer to either immediately correct performance 
or estimate when it would be cost effective to make corrections. In fact, the performance parameters measure how well a TPP produces electricity.

These actions or decisions are [1]:

- Improve TPP operation;

- Predictive maintenance;

- Comparison of actual to expected performance;

- Improved economic dispatch of TPP;

- Reduce uncertainty in actual costs for better MW sales.

This paper can be loosely divided into five parts. First, we present the functionality of TPP. Second, we present the boiler and steam turbine efficiency calculations. In section 3, we present the methodology of the analysis based on the Objectives Oriented Project Planning (OOPP) method. In section 4 , we present the results of the application of system analysis for determining the possible losses for the degradation of the TPP heat rate. The last section presents a conclusion about the advantages and inconveniences of the analysis presented of the TPP heat rate improvement.

\section{Functionality of a thermal power plant}

Thermal power plant (TPP) is a power plant in which the prime mover is steam driven. Water is heated, turns into steam and spins a steam turbine which drives an electrical generator. After it passes through the turbine, the steam is condensed in a condenser. The greatest variation in the design of TPPs is due to the different fuel sources. Some prefer to use the term energy center because such facilities convert forms of heat energy into electrical energy [3-5].

In TPPs, mechanical power is produced by a heat engine which transforms thermal energy, often from combustion of a fuel, into rotational energy. Most TPPs produce steam, and these are sometimes called steam power plants. TPPs are classified by the type of fuel and the type of prime mover installed (Figure 1).

The electric efficiency of a conventional TPP, considered as saleable energy produced at the plant busbars compared with the heating value of the fuel consumed, is typically 33 to $48 \%$ efficient, limited as all heat engines are by the laws of thermodynamics. The rest of the energy must leave the plant in the form of heat.

Since the efficiency of the plant is fundamentally limited by the ratio of the absolute temperatures of the steam at turbine input and output, efficiency improvements require use of higher temperature, and therefore higher pressure, steam.

This overheated steam drags the HP rotor (high pressure) of the turbine in rotation and relaxes to the exit of the HP body of the turbine, so it comes back again in the furnace to be until $540^{\circ}$ 


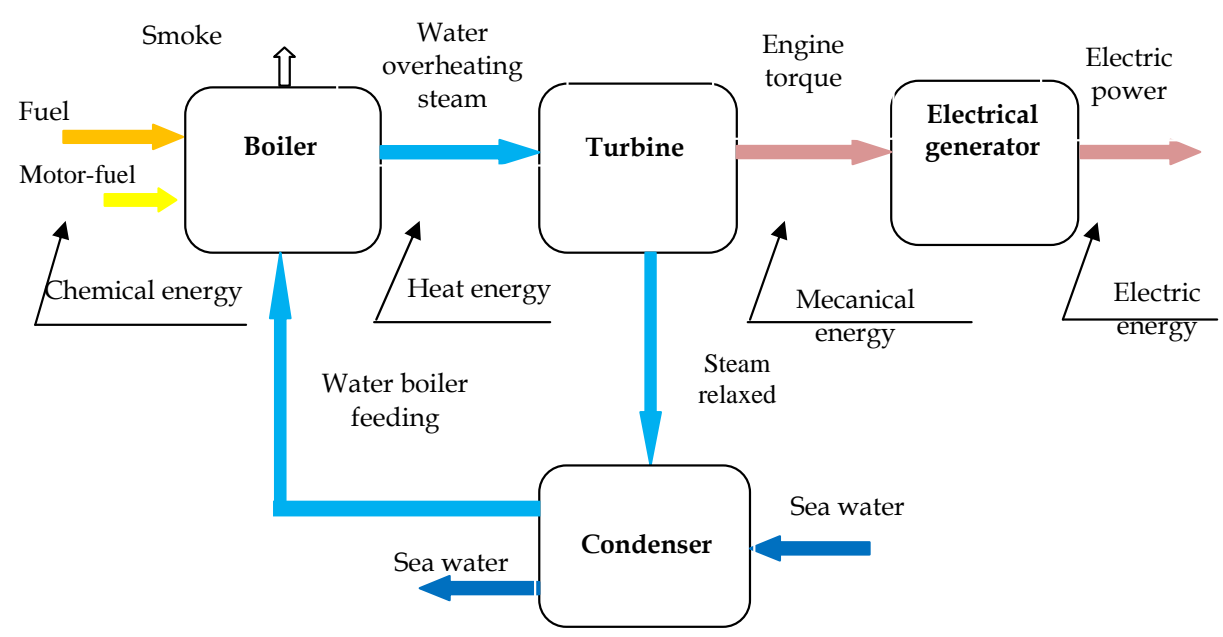

Figure 1. Functionality of a TPP.

after, it will be sent back to the MP body (intermediate pressure) then to the BP body (low pressure) of the turbine.

During these steps, the calorific energy is transformed in available mechanical energy on the turbine. Thus, this mechanical energy will be transmitted to the alternator, being a generator of alternating current, in the goal to produce the electric energy.

After the condensation, water will be transmitted thanks to pumps of extraction in the station of $\mathrm{BP}$ to be warmed progressively before being sent back to the furnace through the intermediary of the food pumps.

This warms progressive of water has for goal to increase the output of the furnace and to avoid all thermal constraints on its partitions. And this station of water is composed of a certain number of intersections that is nourished in steam of the three bodies of the turbine. Finally, the cycle reproduces indefinitely since steam and water circulate in a closed circuit.

During this cycle water recovers the calorific energy in the boiler that it restores at the time of its detente in the turbine as a mechanical energy to the rotor of the turbine. The rotor of the turbine being harnessed to the rotor excited of the alternator, the mechanical energy of the turbine is transformed then in electric energy in the alternator.

Turbine constitutes an evolution exploiting principal's advantages of turbo machines: mass power and elevated volume power; improved efficiency by the multiplication of detente floors [6-8].

Indeed, a steam turbine is a thermal motor with external combustion, functioning according to the thermodynamic cycle Clausius-Rankine. This cycle is distinguished by the state change affecting the motor fluid that is the water steam (Figure 2). 


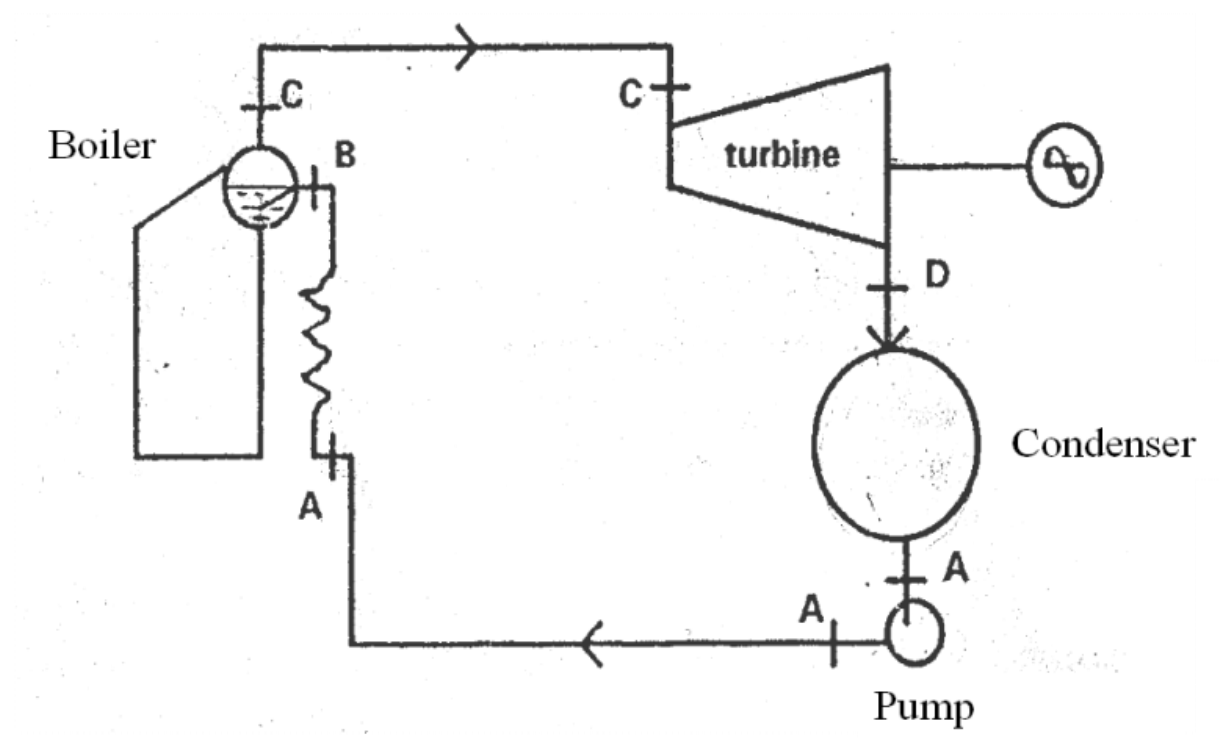

Figure 2. Clausius-Rankine cycle.

The efficiency grows with the steam pressure and with the overheat temperature. However, the increase of these features is limited by the water content in steam in the end of detente.

Indeed, the detente curve can reach the saturation curve with formation of droplets that is harmful to the efficiency of the last floors of detente. The content in liquid water of the mixture must be limited to 15 or $20 \%$. At the end, it is the condenser pressure that fixes the admissible limits of pressure and temperature.

\subsection{Boiler accessories}

The boiler is a steam generator that assures the spraying of water (Figure 3). At this level operates the transformation of the chemical energy in calorific energy by combustion of a mixture "air-fuel".

Figure 3 presents an example of a boiler in a TPP in Tunisia.

The boiler is composed by different elements:

- The combustion room

It constitutes a surrounding wall of contiguous tubular bundles inside in the water circulates. It is in this combustion room the transformation of the chemical energy in calorific energy by combustion of a mixture "air-fuel". This calorific energy frees a quantity of heat that will be transmitted to water to produce the steam of water in a temperature and under a very determined pressure. 


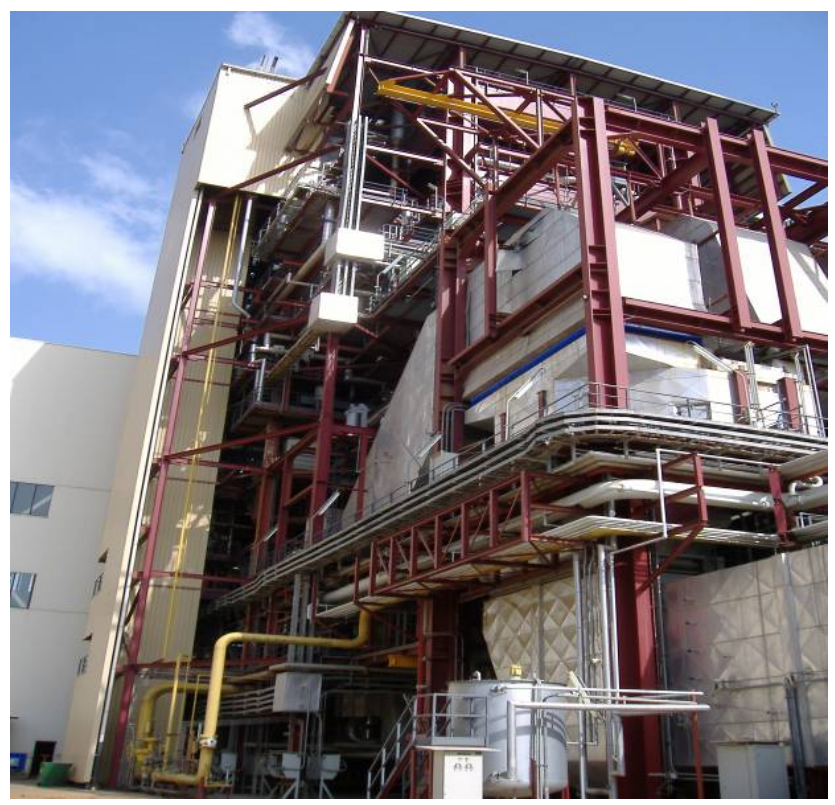

Figure 3. Example of a boiler of a TPP.

- The economiser

It has for role to recover a part of calories remaining in the gases of combustion to increase the temperature of the feeding water what will have for effect the increase of the thermal output of the installation and the elevated thermal constraint suppression in the metal of the reservoir.

- The ball of the boiler

To the exit of the economizer, the water of feeding goes up toward a reservoir situated in the part superior of the boiler called ball of the boiler that constitutes a surrounding wall in sheet metal in which is the liquid phase and the phase steam of the feeding water.

- Superheater / Reheater

It is an intersection of heat constituted of tubular bundles re-serving the gases of combustion directly; therefore submissive to the most elevated temperatures of the combustion room. Steam coming from the ball is humid; it passes therefore in tubes of the heater where its temperature is raised to relatively constant pressure.

After having undergone a first detente in the high pressure body of the turbine, steam comes back to the generator of steam and enter in an intersection called primary reheater of temperature $330^{\circ} \mathrm{C}$ then it crosses the final re-heater of temperature $540^{\circ} \mathrm{C}$, then it is sent toward the intermediate pressure body of the turbine. To the exit of the intermediate pressure body steam passes in the body low pressure of the turbine. 


\section{- Burners}

The burner is the most important component to light the natural gas fuel-oil. Le role of the burner is of creates a zone of ignition to the sufficient temperature to maintain the combustion and to provide the necessary air mixture. The boiler include seven floors each one is equipped of four burners.

\subsection{Steam turbine}

A turbine is constituted of a rotor composed of a tree on which is fixed the dawns and a stator of composed of a structural cover of the stationary deflectors, generally organized of two parts according to an axial plan [9-12].

The turbine is composed of a segmented admission tore and a controlled exhaust divergent toward the condenser. The stationary deflector function is to assure all or one of the detente while forming a nozzles network and to modify the direction of the out-flow retiring of the previous floor.

A steam turbine is composed of one or several floors assuring each two functions:

- The steam detente that corresponds to the conversion of the potential energy in kinetic energy;

- The conversion of the kinetic energy in rotation couple of the machine by the mobile aubages.

The steam turbines are often classified in two big categories combined in the same machine:

- Turbines to action in which the detente makes himself solely in the stationary aubages. They are well adapted to strong pressure floors and are better suitable to the debit regulation. Their construction is more expensive and their use for the first floors.

- The jet-propelled turbines in which the detente is distributed between stationary and mobile aubages. The degree of reaction is defined by the distribution of the detente between aubages. They are better suitable to bass pressure floors and their cost is weaker.

The realization of turbines requires the recourse to greatly allied steels ( $\mathrm{Cr}-\mathrm{Ni}-\mathrm{Va}$ ) to resist the thermal, mechanical constraints (centrifugal force) and chemical (steam corrosion). The first two constraints limit the diameter and therefore the capable debit of the last floors. So dawns besides of one meter of length already put serious problems of realization. Besides, the radial heterogeneity of speeds imposes a variable impact of the dawn that present then a left shape whose machining is complex [9-12].

The principal favour of steam turbines is to be external combustion motors. Of this fact, all fuels (gas, fuel-oil, coal, vestigial, geothermal heat) can be supplied it with steam. The efficiency can reach some elevated values and reduced working expenses (specific consumption of 2300 $\mathrm{kcal} / \mathrm{kWh}$ and $3400 \mathrm{kcal} / \mathrm{kWh}$ for gas turbines). The cost and the complexity of facilities are the most often reserved to the elevated power facilities. But in particular cases, motors and gas turbines are better adapted below about $10 \mathrm{MW}$. 
Figure 4 presents an example of steam turbines in a TPP in Tunisia.

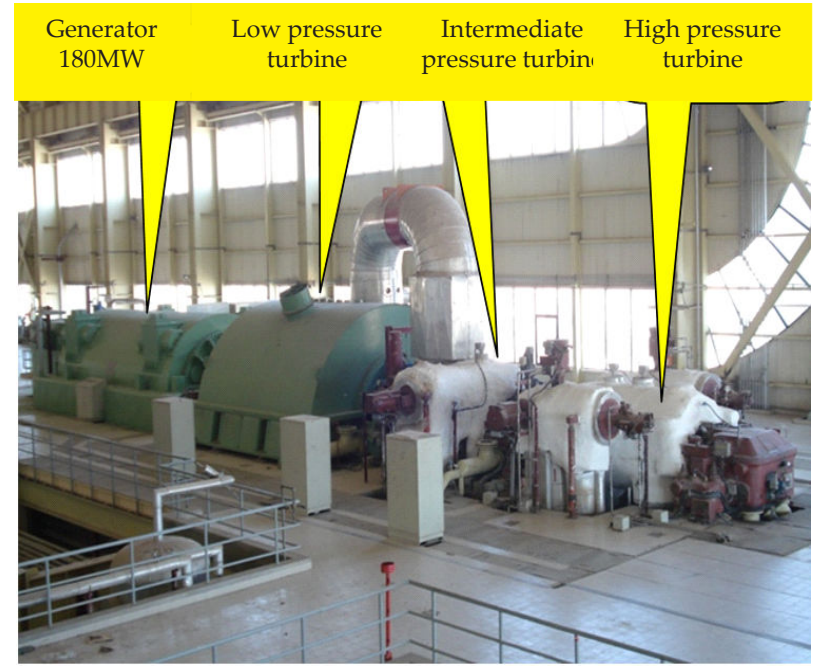

Figure 4. Disposition of steam turbines in a TPP.

\section{Boiler and steam turbine efficiency calculations}

In this paragraph, we present some methods used in order to determine the boiler efficiency and the steam turbine efficiency [13-15].

\subsection{Boiler efficiency calculations}

Among the multiple factors that can degrade the boiler efficiency, there is place to mention what follows as an example:

- bad combustion following a bad working of the regulation;

- bad quality of the fuel used;

- heating inadequate of the used fuel;

- flights of water and steam;

- flights of air (comburant);

- encrassement of the boiler;

- encrassement of the air heating device... 
Boiler efficiency can be calculated by one of two methods: the Input-Output method or the method of heat losses [1].

\subsubsection{Input / output method}

The expression of the boiler efficiency of the TPP is given by:

$$
\mathrm{R}_{\mathrm{ch}}=\frac{\text { Output }}{\text { Input }}
$$

$\mathbf{R}_{\mathrm{ch}}$ : Boiler efficiency.

The exit is defined by the sum of heats absorbed by the used fluid (water-steam).

The entrance is defined by the total energy introduced in the boiler.

The boiler efficiency is given by the following expression:

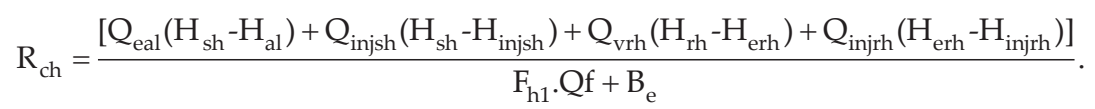

- $\mathrm{Q}_{\text {eal }}$ : debit water $(\mathrm{kg} / \mathrm{h})$;

- $\mathrm{Q}_{\text {injsh }}$ : debit water injection;

- $\mathrm{Q}_{\text {injrh }}$ : debit of the water of steam $(\mathrm{Kg} / \mathrm{h})$.

- $\mathrm{H}_{\mathrm{sh}}$ : enthalpy of steam to the exit;

- $\mathrm{H}_{\mathrm{al}}$ : enthalpy of water in entrance economizer;

- $\mathrm{H}_{\mathrm{rh}}$ : enthalpy of water $(\mathrm{kcal} / \mathrm{kg})$.

- $\mathrm{H}_{\text {erh }}$ : enthalpy of water exit HP (kcal/kg).

- $\mathrm{H}_{\text {injirh }}$ : enthalpy of water ( $\left.\mathrm{kcal} / \mathrm{kg}\right)$.

- $\mathrm{F}_{\mathrm{h} 1}$ : superior calorific power of fuel used (kcal/kg);

- $\mathrm{Q}_{\mathrm{f}}$ : debit fued (t/h);

- $\mathrm{B}_{\mathrm{e}}$ : total of heat introduced.

\subsubsection{Method of heat losses}

The boiler efficiency is given by the following expression: 


$$
\mathrm{R}_{\mathrm{ch}}=\frac{\mathrm{F}_{\mathrm{h}}-\mathrm{C}_{\text {per }}}{\mathrm{F}_{\mathrm{h}}}
$$

$\mathrm{F}_{\mathrm{h}}$ : Total energy introduced in the boiler.

$\mathrm{C}_{\text {per }}$ : Sum of the calorific losses at the level of the boiler.

In the case of fuel, the total heat introduced in the boiler comes from fuel, of the air of combustion and the steam of atomization.

The calorific losses that one meets in a boiler are essentially owed to the heat carried away by the gases of combustion, to the presence of water in fuel as well as the existing humidity in the air of combustion.

\subsection{Steam turbine efficiency calculation}

The calculation of the efficiency of bodies of the turbine with the difference enthalpy method is very useful for the assessment of the cleaning degree of the steam course in the body of the turbine.

The efficiency of the turbine is defined as the report between the real difference enthalpy (DHIHP) and the isotropy difference enthalpy (DHIHP) of steam crossing the HP body.

For the BP body this method is not applicable because of the title of steam to the BP exit (humid steam).

The efficiency of the HP body $(\eta \mathrm{HP})$ is defined as follows [1]:

$$
\eta_{\mathrm{HP}}=\frac{\mathrm{D}_{\text {HRHP }}}{\mathrm{D}_{\mathrm{HIHP}}} \times 100
$$

The real enthalpy difference in the HP body is given by:

$$
\mathrm{D}_{\mathrm{HRHP}}=\mathrm{H}_{\mathrm{vap}}-\mathrm{H}_{\text {erh }}(\mathrm{kcal} / \mathrm{kg})
$$

$\mathrm{H}_{\mathrm{vap}}$ : enthalpy of steam overheated admission HP turbine.

$\mathrm{H}_{\text {erh }}$ : enthalpy of steam to overheat HP exit.

The difference isotropy enthalpy in the HP body is given by:

$$
\mathrm{D}_{\text {HIHP }}=\mathrm{H}_{\mathrm{vap}}-\mathrm{H}_{\text {ith }}
$$


$\mathrm{H}_{\mathrm{ith}}$ : final enthalpy of steam overheated for an expansion isotropy $(\mathrm{S}=$ constant) of the admission until exit of the HP turbine.

In addition the indicated thermodynamic losses appear in the machine external energy losses provoked mainly by rubbings mechanical landings furniture and flights. The efficiency of the turbine must take into account these losses.

The efficiency of the turbine is:

$$
\mathrm{R}_{\mathrm{t}}=\mathrm{R}_{\mathrm{th}} \times \mathrm{R}_{\mathrm{vol}} \times \mathrm{R}_{\mathrm{mec}}
$$

While the volumetric efficiency $\left(\mathrm{R}_{\mathrm{vol}}\right)$ is equal to:

$$
R v o l=1-\frac{g}{G}
$$

g: debit of flight ; G: debit weight.

\section{Methodology of analysis}

There are many methods that have been used to enhance participation in Information System (IS) planning and requirements analysis. We review some methods here because we think them to be fairly representative of the general kinds of methods in use. The methods include Delphi, focus groups, SADT (Structured Analysis Design Technique), multiple criteria decision-making (MCDM), total quality management (TQM) and OOPP method (Objectives Oriented Project Planning).

The objective of the Delphi method is to acquire and aggregate knowledge from multiple experts so that participants can find a consensus solution to a problem [16].

A second distinct method is focus groups (or focused group interviews). This method relies on team or group dynamics to generate as many ideas as possible. Focus groups been used for decades by marketing researchers to understand customer product preferences [17].

MCDM views requirements gathering and analysis as a problem requiring individual interviews [18]. Analysts using MCDM focus primarily on analysis of the collected data to reveal users' requirements, rather than on resolving or negotiating ambiguities. The objective is to find an optimal solution for the problem of conflicting values and objectives, where the problem is modelled as a set of quantitative values requiring optimization.

TQM is a way to include the customer in development process, to improve product quality. In a TQM project, data gathering for customers needs, i.e., requirements elicitation may be done with QFD [19]. 
The SADT method represent attempts to apply the concept of focus groups specifically to information systems planning, eliciting data from groups of stakeholders or organizational teams [20]. They are characterized by their use of predetermined roles for group/team members and the use of graphically structured diagrams. SADT enables capturing of a proposed system's functions and data flows among the functions.

The OOPP method, used in this survey, is considered like a tool of communication, analysis and scheduling of project, whateverisitsnature, its situation, its complexity and its sensitivity [21-24].

In this part, we present the OOPP method that we use in order to determine the different losses of the TPP.

\subsection{OOPP method}

This method is used more and more by several financial backers (World Bank, Union European, bilateral Cooperation...). It is also used to take to terms of development projects, of cooperation (Germany, Canada, Belgium...) or other. It gave a good satisfaction at the time of its exploitation and several researches have been done very well to develop tools and to prove its strength for the scheduling of projects.

The descriptive documentation of the OOPP method, indicate that the logic of the OOPP method is not in principle limited not to a type of a determined problematic. Nevertheless, in practice the method is more appropriated to the following interventions: projects of the technical cooperation and projects of investments with economic and / or social objective.

The OOPP method which is also referred to Logical Framework Approach (LFA) is a structured meeting process. This approach is based on four essential steps: Problem Analysis, Objectives Analysis, Alternatives Analysis and Activities Planning. It seeks to identify the major current problems using cause-effect analysis and search for the best strategy to alleviate these identified problems [21-24].

The first step of "Problem Analysis" seeks to get consensus on the detailed aspects of the problem. The first procedure in problem analysis is brainstorming. All participants are invited to write their problem ideas on small cards. The participants may write as many cards as they wish. The participants group the cards or look for cause-effect relationship between the themes on the cards by arranging the cards to form a problem tree (Figure 5).

In the step of "Objectives Analysis" the problem statements are converted into objective statements and if possible into an objective tree (Figure 6). Just as the problem tree shows causeeffect relationships, the objective tree shows means-end relationships. The means-end relationships show the means by which the project can achieve the desired ends or future desirable conditions.

The objective tree usually shows the large number of possible strategies or means-end links that could contribute to a solution to the problem. Since there will be a limit to the resources that can be applied to the project, it is necessary for the participants to examine these alternatives and select the most promising strategy. This step is called "Alternatives Analysis". 


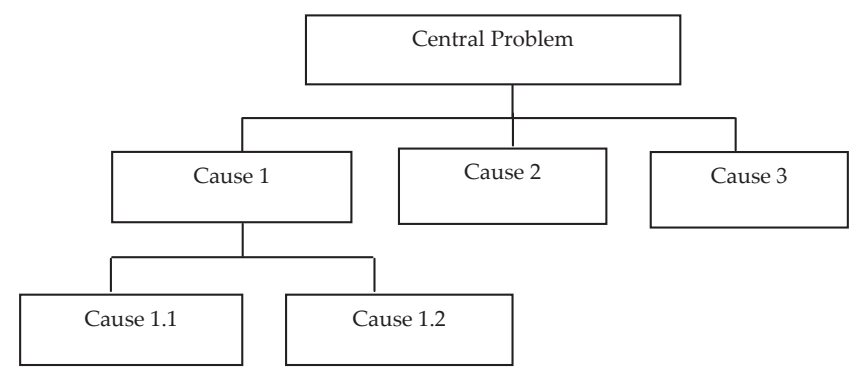

Figure 5. Problem tree of the OOPP method.

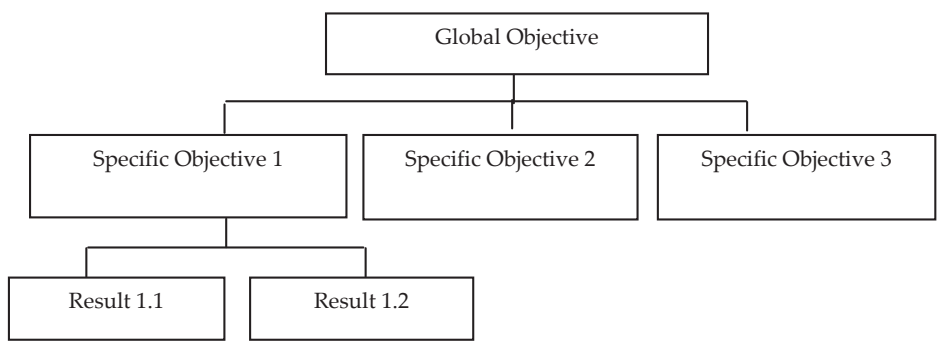

Figure 6. Objective tree of the OOPP method.

After selection of the decision criteria, these are applied in order to select one or more meansend chains to become the set of objectives that will form the project strategy.

After defining the objectives and specifying how they will be measured (Objectively Verifiable Indicators: OVIs) and where and how that information will be found (Means of Verification: MOVs) we get to the detailed planning phase: "Activities Planning". We determine what activities are required to achieve each objective. It is tempting to say; always start at the situation analysis stage, and from there determine who are the stakeholders.

\subsection{Some researches on the OOPP method}

We present some studies of the OOPP method in IS planning that have been presented in various researches:

Researchers, Gu \& al. [25] have presented an object-oriented approach to the development of a generative process planning system. The system consists of three functional modules: objectoriented product model module, object-oriented manufacturing facility model module, and object-oriented process planner.

Researcher, Hill [26] has question the appropriateness of highly structured strategic planning approaches in situations of complexity and change, using the Cambodian-German Health Project as a case study. He has demonstrated the limitations of these planning processes in 
complex situations of high uncertainty, with little reliable information and a rapidly changing environment.

Researchers, Peffers \& al. [27] have used information theory to justify the use of a method to help managers better understand what new Information Technology applications and features will be most valued by users and why and apply this method in a case study involving the development of financial service applications for mobile devices.

Researchers, Killich \& al. [28] have presented the experiences and results of the development and implementation of a software-tool for a SME-network in the German automotive supply chain industry. The tool called TeamUp enables the communication of experts as well as the coordination of discussion groups in order to make use of synergetic potentials.

\subsection{Refining the OOPP method}

The application of the OOPP method to the identification of activities of work stations is important. The management of a system is conditioned notably by ties between its Entities Activities (EA), being able to be according to their hierarchical Specific Objective level (SO), of Results (R), of Activities (TO), of Under-activities (S), of Tasks (T)... These ties are materialized in fact by exchanges of information (If) produced by certain activities and consumed by others. The restraint of these ties requires an extension of the method. This new extension permits to identify the manner to execute these activities and to manage the different phases of the system.

An effort has been provided in order to refine the OOPP method. The OOPP method has been spread and a new denomination MISDIP (Method of Specification, Development and Implementation of Project) was adopted. The MISDIP method adopts the OOPP analysis and the complete it to specify the system of organization, to specify the system of information, and to contribute to its development and implementation [29].

We defined the Method of Informational Analysis by Objectives (MIAO) [30] permitting to elaborate an information matrix that permits to analyze the informational exchange process between activities.

In fact, the identification and the analysis of the information exchanged by the activities indicate the dynamics and the communication between the elements of the system that we propose to study or to manage. So, an information matrix was defined. This matrix establishes a correlation between activities and their information. The information concerning an activity can be classified in two categories:

- The imported information by an activity is supposed to be available: it is either produced by other activity of the system, or coming from outside;

- The produced information by an activity reflects the state of this activity. This last information may be exploited by other activities of the project.

In fact, the information produced by an activity can be considered like a transformation of imported information by this activity. 
In order to specify this information, we define an information matrix (Table 1) associated to OOPP analysis enabling to determine the relations between the activities or between the concerned structures, to identify the information sources and to determine the manner in which the information is exploited.

\begin{tabular}{|l|l|l|l|l|l|l|l|l|l|l|l|}
\hline $\mathbf{N}^{\circ}$ & Code & Activity & If $_{1}$ & If $_{2}$ & If $_{3}$ & If $_{4}$ & If $_{5}$ & If $_{6}$ & If $_{7}$ & If $_{8}$ & If $_{\mathbf{n}}$ \\
\hline 1 & & $\mathrm{~A}_{1}$ & 0 & 0 & 1 & 1 & & & & & \\
\hline 2 & & $\mathrm{~A}_{2}$ & & 0 & 0 & & 1 & 0 & & & \\
\hline 3 & & $\mathrm{~A}_{3}$ & 1 & 0 & 0 & 0 & & 0 & 0 & 1 & \\
\hline 4 & & $\mathrm{~A}_{\mathbf{n}}$ & & & & & & & & & \\
\hline
\end{tabular}

Table 1. The information matrix of the MIAO.

To make sure of the quality of information system, we define some logic-functional rules reflecting the coherence, the reliability and the comprehensiveness of the analysis by an information matrix in which the rows are relating to activities and the columns to information.

In order to become the exploitation of the information matrix more comfortable, we define the Method of Representation of the Information by Objectives (MRIO) [31] inspiring of the SADT method (Structured Analysis Design Technique) and we define its tools.

\section{Results of the system analysis and correctives actions}

In this part, we present the results of the system analysis of a TPP whose objective is to determine the possible reasons of the degradation of the TPP heat rate. In fact, all events that are appropriate (preventive or corrective maintenance, exploitation, in conformity of modification, related to working, work stops...) are consigned on GMAO in the TPP in order to constitute the historic and to permit the traceability. This historic has been consulted in the goal to bring a more for the possible problems research.

The objectives tree (presented in linear form) presents ten specific objectives enabling to lead the global objective (GO): TPP heat rate losses identified.

These specific objectives are: Boiler losses identified; Condensate/FW system losses identified; Circulating water system losses identified; Turbine losses identified; Steam conditions losses identified; Electrical auxiliary losses identified; Steam auxiliary losses identified; Fuel handling losses identified; Heat losses identified; Cycle isolation losses identified.

Table 2 presents the OOPP analysis of the TPP heat rate losses. 


\begin{tabular}{lll}
\hline $\mathbf{N}^{\circ}$ & Code & Activity \\
\hline 1 & GO & TPP heat rate losses identified \\
\hline 2 & SO1 & Boiler losses identified \\
\hline 3 & SO2 & Condensate/FW system losses identified \\
\hline 4 & SO3 & Circulating water system losses identified \\
\hline 5 & SO4 & Turbine losses identified \\
\hline 7 & SO5 & Steam conditions losses identified \\
\hline 8 & SO6 & Electrical auxiliary losses identified \\
\hline 9 & SO8 & Steam auxiliary losses identified \\
\hline 10 & SO9 & Fuel handling losses identified \\
\hline
\end{tabular}

Table 2. OOPP analysis.

The final production of the application of the OOPP method enabled us to answer clearly to the question «what? ». Then, we presented the different results of the OOPP analysis to enable us identifying the different losses at the level of the TPP and to improve the TPP heat rate.

Figures 7 presents the objectives analysis related to the losses at the level of the boiler.

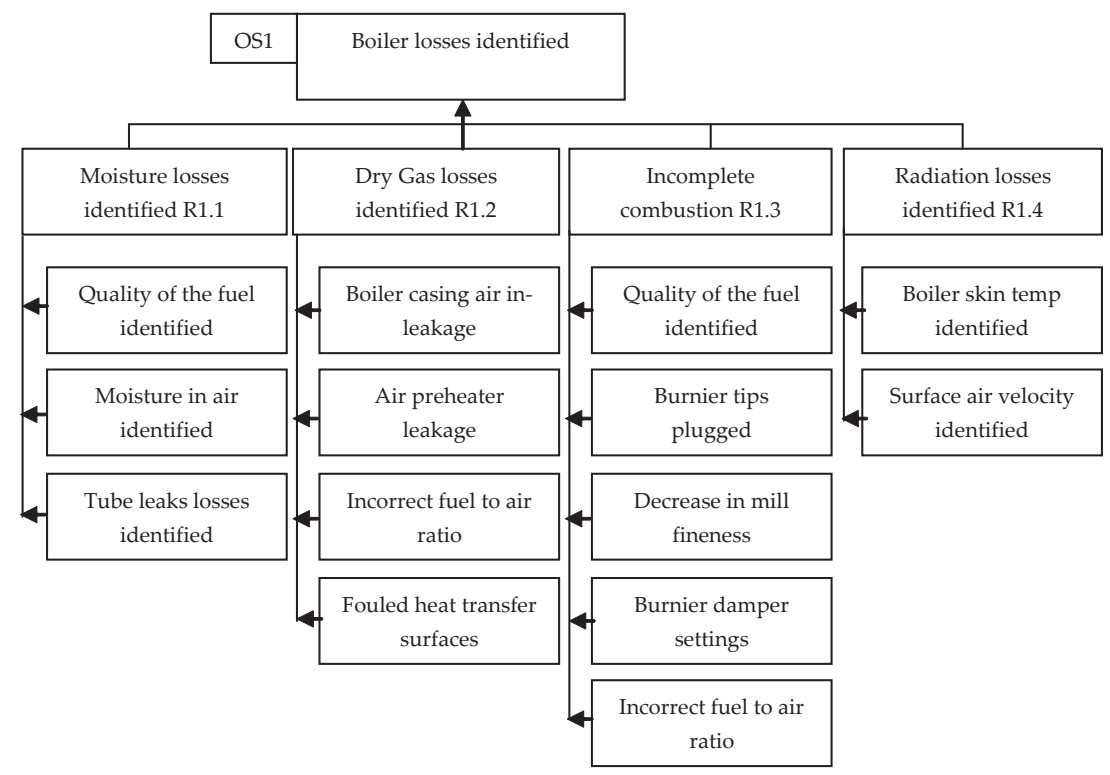

Figure 7. Objective tree of the boiler losses.

For example, the result R1.1 is decomposed in three intermediary results: Quality of the fuel identified; Moisture in air identified; Tube leaks losses identified. 
Figures 8 presents the objectives analysis related to the losses at the level of the steam turbine.

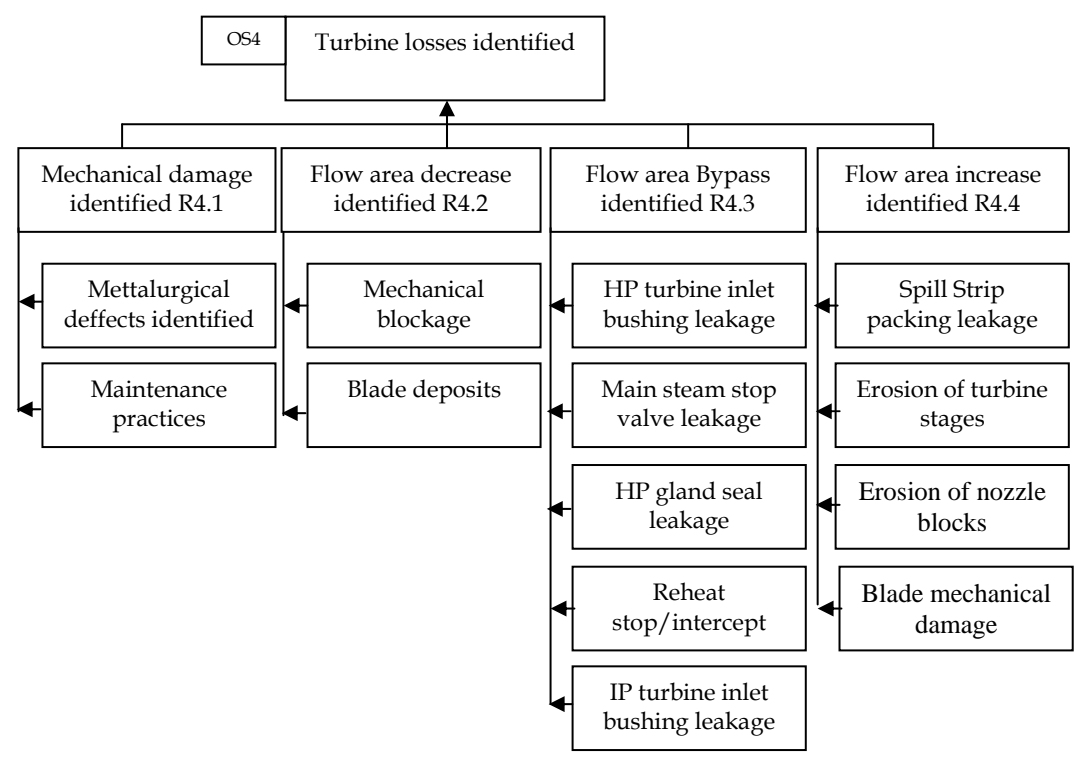

Figure 8. Objective tree of the Turbine losses.

Figures 9 presents the objectives analysis related to the losses at the level of the Electrical auxiliary.

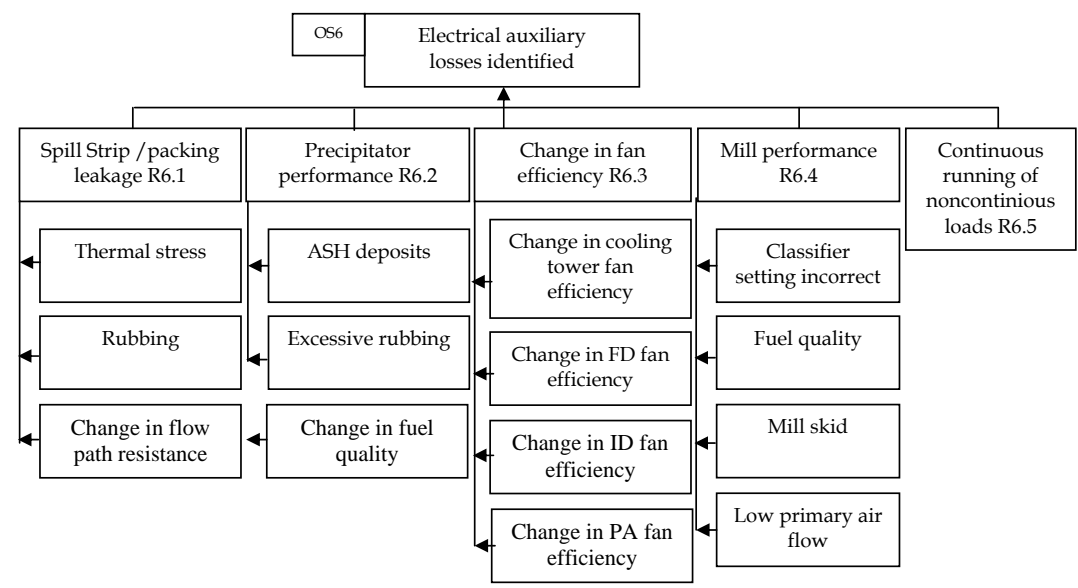

Figure 9. Objective tree of the Electrical auxiliary losses. 
Table 3 presents some performance parameters that measure how well the TPP is doing its job in producing electricity. Then, we present in the last column some corrections actions that should be made to improve thermodynamic efficiency and to improve TPP's overall performance.

\begin{tabular}{|c|c|c|c|}
\hline Parameter & Cause & $\begin{array}{l}\text { Test } \\
\text { of confirmation }\end{array}$ & $\begin{array}{l}\text { Corrective } \\
\text { action }\end{array}$ \\
\hline \multirow{2}{*}{$\begin{array}{l}\text { Pressure steam } \\
\text { of the } \\
\text { admission } \\
\text { turbine } \\
\text { very high }\end{array}$} & Instrument error & $\begin{array}{l}\text { To verify with the redundant measures } \\
\text { To compare with pressures in relation as } \\
\text { (pressure exit over heater, ball) }\end{array}$ & To calibrate instruments \\
\hline & $\begin{array}{l}\text { No consistency } \\
\text { with the order } \\
\text { point }\end{array}$ & $\begin{array}{l}\text { To verify if floodgates of control of the } \\
\text { turbine are opened completely and the } \\
\text { pressure remains even high: the coefficient } \\
\text { of evaporation debit in the furnace is very } \\
\text { low }\end{array}$ & $\begin{array}{c}\text { To verify the order point of the } \\
\text { pressure entrance turbine; } \\
\text { To see the regulation system }\end{array}$ \\
\hline \multirow{6}{*}{$\begin{array}{l}\text { Temperature } \\
\text { steam of the } \\
\text { admission } \\
\text { turbine } \\
\text { very low }\end{array}$} & Instrument error & $\begin{array}{l}\text { To verify with the redundant measures } \\
\text { To compare with temperatures in relation as } \\
\text { the difference with the temperature steam } \\
\text { admission turbine must be between } 0 \text { and } \\
\qquad 15^{\circ} \mathrm{C}\end{array}$ & To calibrate instruments \\
\hline & $\begin{array}{l}\text { Pressure stem } \\
\text { admission } \\
\text { turbine high }\end{array}$ & $\begin{array}{l}\text { Pressure steam } \mathrm{SH} \text { is a performance } \\
\text { parameter }\end{array}$ & \\
\hline & $\begin{array}{l}\text { Debit injection } \\
\text { SH }\end{array}$ & $\begin{array}{l}\text { To verify the debit of injection: the debit of } \\
\text { injection is a performance parameter }\end{array}$ & \\
\hline & $\begin{array}{c}\text { Encrassement of } \\
\text { exchange } \\
\text { surfaces } \mathrm{SH}\end{array}$ & $\begin{array}{l}\text { Test integrity of the furnace: } \\
\text { factor of tube encrassement }\end{array}$ & To eliminate the encrassement \\
\hline & Low excess of air & $\begin{array}{l}\text { To verify the excess of air: the excess of air is } \\
\text { a performance parameter }\end{array}$ & \\
\hline & Order point low & To verify the order point & $\begin{array}{l}\text { To increase the value of the } \\
\text { order point }\end{array}$ \\
\hline \multirow{2}{*}{$\begin{array}{l}\text { Debit injection } \\
\text { SH very high }\end{array}$} & Instrument error & $\begin{array}{l}\text { To verify with the redundant } \\
\text { measures ; } \\
\text { To calculate the debit from the temperature } \\
\text { entrance and exit heating }\end{array}$ & To calibrate instruments \\
\hline & $\begin{array}{l}\text { Order point of } \\
\text { steam } \\
\text { temperature very } \\
\text { low }\end{array}$ & To verify the order point steam temperature & $\begin{array}{l}\text { To increase the value of the } \\
\text { order point }\end{array}$ \\
\hline
\end{tabular}




\begin{tabular}{|c|c|c|c|}
\hline Parameter & Cause & $\begin{array}{c}\text { Test } \\
\text { of confirmation }\end{array}$ & $\begin{array}{l}\text { Corrective } \\
\text { action }\end{array}$ \\
\hline & $\begin{array}{l}\text { Debit injection } \\
\text { on manual order } \\
\text { point very high }\end{array}$ & To see system of regulation & $\begin{array}{l}\text { To adjust the station of control } \\
\text { of injection debit }\end{array}$ \\
\hline & $\begin{array}{l}\text { Very high air } \\
\text { excess }\end{array}$ & $\begin{array}{l}\text { To verify the excess of air: } \\
\text { (performance parameter) }\end{array}$ & \\
\hline & $\begin{array}{l}\text { Low water } \\
\text { temperature: }\end{array}$ & & \\
\hline & $\begin{array}{l}\text { a- by-pass HP } \\
\text { heating }\end{array}$ & $\begin{array}{l}\text { To verify temperature water before and } \\
\text { after by-pass HP }\end{array}$ & $\begin{array}{c}\text { To close floodgate by-pass HP } \\
\text { heating device } \\
\text { To eliminate the flights }\end{array}$ \\
\hline & $\begin{array}{l}\text { B High TD } \\
\text { heating HP }\end{array}$ & $\begin{array}{l}\text { To verify TD heating HP : } \\
\text { (performance parameter) }\end{array}$ & \\
\hline & $\begin{array}{l}\text { Very low } \\
\text { pressure steam } \\
\text { admission } \\
\text { turbine }\end{array}$ & To verify pressure steam admission turbine & \\
\hline & $\begin{array}{l}\text { Flight floodgate } \\
\text { control of } \\
\text { injection }\end{array}$ & $\begin{array}{l}\text { To close the floodgate of insulation ; } \\
\text { To verify if the conduct is hot }\end{array}$ & To repair the floodgate \\
\hline \multirow{7}{*}{$\begin{array}{l}\text { Debit injection } \\
\text { RH very high }\end{array}$} & Instrument error & $\begin{array}{l}\text { To calculate the debit of steam from the } \\
\text { temperature of entrance and exit }\end{array}$ & \\
\hline & $\begin{array}{l}\text { Very low order } \\
\text { point of } \\
\text { temperature } \\
\text { steam }\end{array}$ & To verify the order point & $\begin{array}{l}\text { To increase the value of the } \\
\text { order point }\end{array}$ \\
\hline & $\begin{array}{l}\text { Very high debit } \\
\text { injection on } \\
\text { manual order } \\
\text { point }\end{array}$ & To verify the control station & To adjust the control station \\
\hline & $\begin{array}{l}\text { Very high air } \\
\text { excess }\end{array}$ & $\begin{array}{l}\text { To verify the air excess } \\
\text { (performance parameter) }\end{array}$ & \\
\hline & $\begin{array}{l}\text { Low water } \\
\text { temperature: }\end{array}$ & & \\
\hline & $\begin{array}{l}\text { a- by-pass } \\
\text { heating HP }\end{array}$ & $\begin{array}{l}\text { To verify temperature water before and } \\
\text { after by-pass HP }\end{array}$ & $\begin{array}{c}\text { To close floodgate by-pass HP } \\
\text { heating ; To eliminate the } \\
\text { flights }\end{array}$ \\
\hline & $\begin{array}{l}\text { B High TD } \\
\text { heating HP }\end{array}$ & $\begin{array}{l}\text { To verify TD heating HP: } \\
\text { (performance parameter) }\end{array}$ & \\
\hline
\end{tabular}




\begin{tabular}{|c|c|c|c|}
\hline Parameter & Cause & $\begin{array}{l}\text { Test } \\
\text { of confirmation }\end{array}$ & $\begin{array}{l}\text { Corrective } \\
\text { action }\end{array}$ \\
\hline & $\begin{array}{l}\text { Very low } \\
\text { pressure steam } \\
\text { admission } \\
\text { turbine }\end{array}$ & To verify pressure steam admission turbine & \\
\hline & $\begin{array}{c}\text { Flight floodgate } \\
\text { control of } \\
\text { injection }\end{array}$ & $\begin{array}{l}\text { To close the floodgate of insulation; } \\
\text { To verify if the conduct is hot }\end{array}$ & To repair the floodgate \\
\hline & $\begin{array}{c}\text { Very low } \\
\text { temperature } \\
\text { vapeur } \\
\text { admission } \\
\text { turbine }\end{array}$ & $\begin{array}{c}\text { To verify temperature steam admission } \\
\text { turbine }\end{array}$ & \\
\hline & $\begin{array}{c}\text { Very low } \\
\text { efficiency HP } \\
\text { turbine }\end{array}$ & To verify the efficiency of the HP turbine & \\
\hline
\end{tabular}

Table 3. Diagnosis of performance parameters and corrective actions.

\section{Conclusion}

The performance of a TPP will begin to decline as the thermal power plant (TPP) begins to age. A good performance program will be able to identify these losses of the degradation of the heat rate. A more accurate knowledge of TPP heat rates can improve economic dispatching costs and ensure that profits are maintained on a daily basis.

In fact, the performance parameters measure how well the TPP is doing its job in producing electricity. Decisions should not necessarily be made only to improve thermodynamic efficiency, but rather to improve TPP's overall performance.

In this paper, we presented an exploration of the ways permitting the improvement of the TPP heat rate. This is why we presented a practical case of a TPP in Tunisia. The objective is to determine the possible causes generating losses and provoking the degradation of the TPP heat rate while using a system analysis method.

To reach this objective, System Analysis methods seem to be a promising way because the major advantage of these kinds of methods is due to the concept of hierarchy activity. These methods permit the complexity of a system to be overcome. In this paper, the application of the OOPP method on a real system, a thermal power plant in Tunisia generates a source of useful information for determining of the possible losses at the level of a TPP. So, research into the application of System Analysis methods must be intensified in order to solve several difficulties and to improve their efficiency. 


\section{Author details}

M.N. Lakhoua ${ }^{1 *}$, M. Harrabi ${ }^{2}$ and M. Lakhoua ${ }^{2}$

*Address all correspondence to: MohamedNajeh.Lakhoua@ieee.org

1 Université de Tunis El Manar, Ecole Nationale d'Ingénieurs de Tunis, LR11ES20 Analyse, Conception et Commande des Systèmes, Tunis, Tunisie

2 Société Tunisienne de l’Electricité et du Gaz, Tunisie

\section{References}

[1] Heat Rate Improvement Reference Manual, EPRI, Palo Alto, CA, TR-109546, Jully1998.

[2] Heat Rate Improvement Guidelines for Existing Fossil Plants, Electric Power Research Institute, Palo Alto, CA: May 1986. Report CS-4554.

[3] A. Vitaly, Alternative trends in development of thermal power plants, Applied Thermal Engineering, 28, Issues 2-3, 2008, pp. 190-194.

[4] V. Slobodan; P. Nikola and D. Željko; Power Electronics Solution to Dust Emissions from Thermal Power Plants, Serbian journal of electrical engineering, Vol.7. $\mathrm{N}^{\circ}$, 2010.

[5] M.N. Lakhoua, SCADA applications in thermal power plants, International Journal of the Physical Sciences, vol.5, N7, 2010, pp. 1175-1182.

[6] M. T. Khadir and S. Klai, A steam turbine diagnostic maintenance system based on an evolutive domain ontology, International Conference on Machine and Web Intelligence (ICMWI), 2010, pp. 360- 367.

[7] M. Yufeng and L. Yibing, An Hongwen; Statistical analysis of steam turbine faults, International Conference on Mechatronics and Automation (ICMA), 2011, pp. 24132417.

[8] H. Qing, D. Dongmei and L. Hong, Research on Web System of Intelligent Diagnosis for Steam Turbine, Chinese Control Conference (CCC2006), 2006, pp. 1271- 1275.

[9] J. Klure-Jensen and R. Hanisch, Integration of steam turbine controls into power plant systems, IEEE Transactions on Energy Conversion, Vol.6, Issue: 1, 1991, pp. 177- 185. 
[10] L.N. Bize and J.D. Hurley, Frequency control considerations for modern steam and combustion turbines, IEEE Power Engineering Society 1999 Winter Meeting, Vol.1, 1999, pp. 548- 553.

[11] I.C. Report, Bibliography of Literature on Steam Turbine-Generator Control Systems, IEEE Transactions on Power Apparatus and Systems, Volume: PAS-102, Issue: 9, 1983, pp. 2959- 2970.

[12] W. Jianmei, C. Kai and M. Xinqiang, Optimization Management of Overhaul and Maintenance Process for Steam Turbine, ICIII '08, Vol .3, 2008, pp. 244- 247.

[13] Spécification du calcul de performance ANSALDO Energia 4150 AO VVH I 082.

[14] Norm ASME PTC 4.1- Steam generating units.

[15] FDX 60-000, Normalisation Française, Mai 2002.

[16] R.M. Roth, W.C.I. Wood and A.Delphi, Approach to acquiring knowledge from single and multiple experts, Conference on Trends and Directions in Expert Systems, 1990.

[17] M. Parent, R.B. Gallupe, W.D. Salisbury and J.M. Handelman, Knowledge creation in focus groups: can group technologies help? Information \& Management 38 (1), pp. 47-58, 2000.

[18] H.K. Jain, M. R. Tanniru and B. Fazlollahi, MCDM approach for generating and evaluating alternatives in requirement analysis. Information Systems Research 2 (3), pp. 223-239, 1991.

[19] C. Stylianou, R. L. Kumar and M. J. Khouja, A Total Quality Management-based systems development process. The DATA BASE for Advances in Information Systems 28 (3), pp. 59-71, 1997.

[20] K. Schoman, D.T. Ross, Structured analysis for requirements definition, IEEE Transaction on Software Engineering 3 (1), pp. 6-15, 1977.

[21] The Logical Framework Approach (LFA): Handbook for objectives-oriented planning, Norad, Fourth edition, 1999.

[22] ZOPP: An Introduction to the Method, COMIT Berlin, May 1998.

[23] GTZ, Methods and Instruments for Project Planning and Implementation, Eschborn, Germany, 1991.

[24] AGCD, Manuel pour l'application de la «Planification des Interventions Par Objectifs (PIPO)», 2ème Edition, Bruxelles, 1991.

[25] P. Gu and Y. Zhang, OOPPS: an object-oriented process planning system, Computers \& Industrial Engineering, Vol.26, Issue 4, pp. 709-731, 1994. 
[26] S. H. Peter., Planning and change: a Cambodian public health case study, Social Science \& Medicine, 51, pp.1711-1722, 2000.

[27] K. Peffers, Planning for IS applications: a practical, information theoretical method and case study in mobile financial services, Information \& Management, Vol.42, Issue 3, pp. 483-501, 2005.

[28] S. Killich and H. Luczak, Support of Interorganizational Cooperation via TeamUp at Internet-Based Tool for Work Groups, Proceedings of the 6th internationally Scientific Conference, Berchtesgaden, May 22-25, Berlin, 2002.

[29] M. Annabi, PIPO étendue : Méthode Intégrée de Spécification, de Développement et d'Implémentation de Projet (MISDIP), International conference on Sciences and Techniques of Automatic control and computer engineering STA'2003, Sousse, 2003.

[30] M.N. Lakhoua, Refining the objectives oriented project planning (OOPP) into method of informational analysis by objectives, International Journal of the Physical Sciences, Vol.6(33), pp. 7550 - 7556, 2011.

[31] Lakhoua, M. N. \& Ben Jouida T., Refining the OOPP into Method of Representation of the Information by Objectives, International Transactions on Systems Science and Applications, Vol. 7, No. 3/4, December 2011, pp. 295-303. 